\title{
Inhibition of Catalase Isozymes of Helicoverpa armigera(Lepidoptera: Noctuidae) by Salicylic acid.
}

\author{
Hanumanth Goud $\mathrm{G}^{1}$, Ravindra M Aurade ${ }^{2}$, Jayalakshmi S.K ${ }^{3}$, Sreeramulu $\mathrm{K}^{4}$ \\ 1,2,4 Department of Biochemistry, Gulbarga University, Gulbarga, India. \\ ${ }^{3}$ Agricultural Research Station (University of Agricultural Sciences-Raichur), Gulbarga, India.
}

\begin{abstract}
The cotton bollworm, Helicoverpa armigera is a polyphagous pest and causes oxidative damage to field crops. Salicylic acid is the cell signaling molecule produced in response to insect attack on plants. Catalase plays a major role in the protection of tissues from the toxic effects of $\mathrm{H}_{2} \mathrm{O}_{2}$ and partially reduced oxygen species. Invitroand Invivo effect of salicylic acid was studied on the activities of catalases of Helicoverpa armigera, and tissue distribution of catalase isoforms was also studied. Eight catalase isoforms were found in the gut and whole body preparations whereas single isoforms in the hemolymph. Salicylic acid inhibited over $90 \%$ of catalase activity at $2 \mathrm{mM}$ concentrations in the gel activity staining as well as spectrophotometrically, but catalase I in all the preparations are stable and insensitive to salicylic acid.
\end{abstract}

Key words: Catalase, Helicoverpa armigera, Inhibition, Salicylic acid.

\section{Introduction}

Helicoverpa armigera (Hubner) (Lepidoptera: Noctuidae), is a polyphagous pest attacking more than 200 different plant species including cotton, grain legumes, cereals, vegetables and fruits. Control of $H$. armigera is heavily based on insecticides; as a result pest has developed high levels of resistance to commonly used insecticides [1]. The exposure of chemicals to tissues and cells results in the induction of a reactive oxygen species (ROS) such as $\mathrm{H}_{2} \mathrm{O}_{2}$ and superoxide anion. In general, ROS is harmful to living organisms because ROS tends to give oxidative damages to proteins, nucleic acids, and lipids [2]. In this regard, ROS has been recognized to be related to aging and life span [3-4]. Antioxidant enzymes are typical factors facilitating the scavengery of ROS.Catalase (EC 1.11.1.6, CAT) is one of the antioxidant enzymes involved in regulating the cellular level of active oxygen species. Catalase converts $\mathrm{H}_{2} \mathrm{O}_{2}$ to water and oxygen, hence protecting cells from the damaging effect of $\mathrm{H}_{2} \mathrm{O}_{2}$.

Plants are continuously exposed to the challenge of a variety of herbivores. Plants have evolved constitutive and inducible defense mechanisms against the herbivores. Salicylic acid and jasmonic acid (JA) function as signaling molecules in plants, mediating induced plant responses against herbivory and pathogen infection, leading to the activation of genes mediating host plant resistance to insects [5]. More recently, elevated levels of SA have been found to be associated with herbivore attack in tomato plants [6]. Although the hemolymph is known to generate ROS [7], and thus is not immune to oxidative damage, the hemolymph possesses very low or negligible activities of most antioxidant enzymes SOD, CAT, GST and GR [8]. Most of the enzymes occur at high levels in metabolically active tissues such as fat body, midgut and malphigian tubules. There has been limited study on determining the tissue location of antioxidants in insects [9].The presence of antioxidant enzymes in the digestive lumen, with the exception of catalase is largely unknown and warrants further study.

Salicylic acid (SA) and its analogues have adverse effects on the growth, development, oxidative phosphorylation, mitochondrial dysfunction and accumulation of $\mathrm{H}_{2} \mathrm{O}_{2}$ [10]. SA was shown to be a potent inhibitor of plant and animal catalases [11-12]. Since the level of SA increases during insect and pathogen attack, as well as during exogenous application induces defense mechanism in plants. The present studies were therefore undertaken to determine whether SA could inhibit catalase isozymes of $H$. armigera.

\section{Materials and methods}

2.1 Insects

The pests that had developed resistance to various insecticides were supplied by Dr. S.S. Udikeri, Agriculture Research Station, University of Agricultural Sciences, Dharwad, India. The larvae were reared on a chickpea based semi-synthetic diet containing with or without $2 \mathrm{mM} \mathrm{SA}$ under laboratory conditions at $27 \pm 1$ ${ }^{\circ} \mathrm{C}, 65 \pm 5 \% \mathrm{RH}$, and $12 \mathrm{~h}$ photoperiod. Bioassay was carried out according to out earlier report[10].

2.2 Enzyme extraction

Fourth instar larvae were washed with cold $20 \mathrm{mM}$ Tris-HCl buffer $\mathrm{pH}$ 7.0. Hemolymph was collected by following the method [13]. The gut contents and the whole body were separately homogenized in $50 \mathrm{mM}$ 
Inhibition of catalase isozymes of Helicoverpa armigera (Lepidoptera: Noctuidae) by salicylic acid.

Tris-HCl buffer $\mathrm{pH} 7.0$ containing $1 \mathrm{mM}$ PMSF and centrifuged for $30 \mathrm{~min}$ at 10,000 g. The supernatant was used as enzyme source. Protein concentration was determined by Lowry et al [14] using bovine serum albumin as standard.

\subsection{Catalase activity}

Catalase catalyzed the decomposition of $\mathrm{H}_{2} \mathrm{O}_{2}$ was monitored by the decrease in the absorbance at $240 \mathrm{nmspectrophotometrically} \mathrm{over} \mathrm{a} \mathrm{period} \mathrm{of} 3 \mathrm{~min}$. One unit of catalase activity was expressed as the amount of enzyme capable of catalyzing the degradation of one micromoles of hydrogen peroxide reduced per minute per milligram of protein, using an extinction coefficient of $39.4 \mathrm{mM}^{-1} \mathrm{~cm}^{-1}[15]$.

\subsection{Native PAGE and activity staining}

Equal amount of protein from fat body, midgut and hemolymph were subjected to native PAGE using $8 \%$ polyacrylamide gel was carried out by the Davis method [16] under non-reducing conditions. Catalase isoforms were visualized following the modified method [17]. Briefly gels were soaked in $3 \mathrm{mM} \mathrm{H}_{2} \mathrm{O}_{2}$ for 10 $\mathrm{min}$ at room temperature. Then gels were soaked in staining solution containing $1 \%$ potassium ferricyanide and $1 \%$ ferric chloride. Catalase isozymes were visualized immediately.

\section{Results and Discussion}

In insects, catalases are recognized to be responsible for the scavenging of reactive oxygen species [18] as they are deficient in a selenium dependent glutathione peroxidase, which is another scavenger present in the other organisms [19]. The midgut and whole body preparations shows high activity of 40 and $37 \mathrm{units} / \mathrm{mg}$ of protein but very less activity of 8 units $/ \mathrm{mg}$ with hemolymph preparations. The catalases are widely distributed in various tissues of $H$. armigera larvae and found highest activity in whole body preparation. Among the different tissues, highest activity was detected in the liver extract of the mouse [20]. In in-vitro assay the catalase activity were inhibited by $90 \%$ at $2 \mathrm{mM}$ of SA, except for hemolymph catalase (Table 1). Further isoforms of catalases were analyzed by gel activity staining in control and SA treated larvae. Fig 1A shows the tissue distribution of catalase in control larvae and found 8 catalase isoforms in the gut and whole body preparations whereas single isoform in hemolymph. The catalase isoforms 3, 7, 8 of gut and 3, 4, 5 of whole body preparation were in low levels. The larvae fed with $2 \mathrm{mM} \mathrm{SA}$ were found to inhibit all the catalases except CAT 1 from all the preparations (Fig 1B). Akbar et al [10] have reported that $H$. armigera larvae fed the diet containing $2 \mathrm{mM} \mathrm{SA}$ was found to accumulate high content of $\mathrm{H}_{2} \mathrm{O}_{2}$ in the cells and also the larval weight was decreased by around $70 \%$. This further supports our results that SA inhibited catalases of $\mathrm{H}$. armigera that led to accumulate $\mathrm{H}_{2} \mathrm{O}_{2}$ in vivo, which might be causing the oxidative damage to the cell. Hence the studies reveal that treatment with SA would be helpful to arrest the growth of H. armigera larvae.

\section{Figures and Tables}

TABLE 1: Catalase activity in different tissues of $\boldsymbol{H}$. armigera.

Tissue Catalase activity (Units/mg)

Control Treated with SA $(2 \mathrm{mM})$

\begin{tabular}{lll}
\hline Gut extract & $40.89 \pm 2.21$ & $5.45 \pm 3.20$ \\
Whole body & $37.12 \pm 1.5$ & $4.32 \pm 2.0$ \\
Hemolymph & $8.89 \pm 0.92$ & $8.89 \pm 0.92$
\end{tabular}

Values are representation of mean \pm SD $(n=3)$

Fig 1: Tissue distribution of catalase isozymes. A-control pests, B; Pests treated with 2 mM SA. lane1, gut extract; lane 2, whole body preparation; lane 3, Hemolymph.

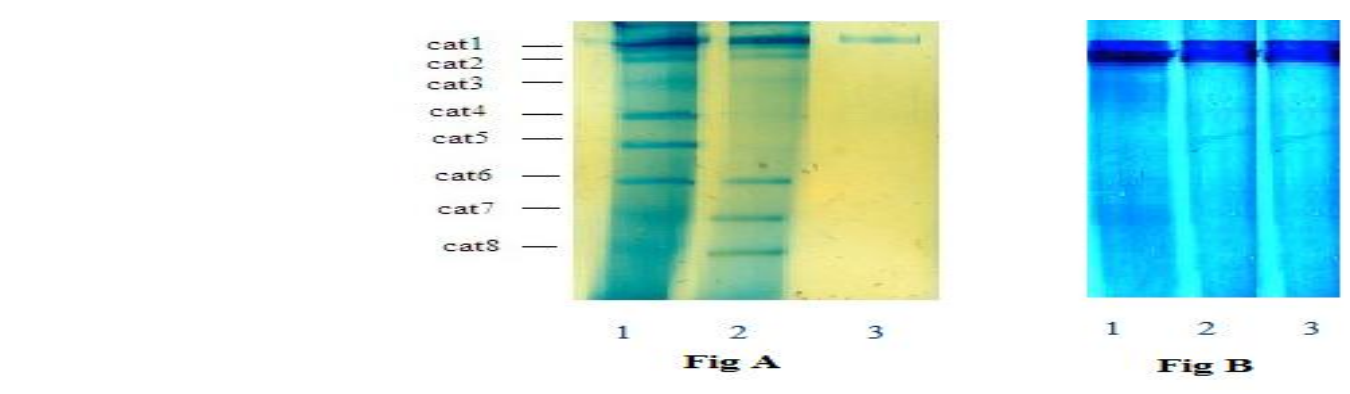




\section{Conclusion}

The research reveals the in vitro and in vivo effect of salicylic acid on the catalase isozymes of Helicoverpa armigera and shown the application of salicylic acid would be helpful to arrest the growth of Helicoverpa armigera.

\section{Acknowledgements}

This research was supported by a research grant to K. Sreeramulu from the Department of Science and Technology and SAP of University Grant Commission, New Delhi, India. Resistant pests were provided by Dr. S.S. Udikeri, Agriculture Research Station, University of Agricultural Sciences, Dharwad, India.

\section{References}

[1] R. Srinivas, S. S. Udikeri, S. K. Jayalakshmi, and K. Sreeramulu, Identification of factors responsible for insecticide resistance in Helicoverpa armigera,Comparitive Biochemistry Physiology C Toxicology Pharmacology, 137 (3), 2004, $261-269$.

[2] M. Hermes-Lima, and T. Zenteno-Savín, Animal response to drastic changes in oxygen availability and physiological oxidative stress,Comparitive Biochemistry Physiology C Toxicology Pharmacology, 133,2002, 537-56.

[3] W.C. Orr, and R.S. Sohal, Extension of life-span by overexpression of superoxide dismutase and catalase in Drosophila melanogaster,Science, 263,1994,1128-30.

[4] T.L. Parkes, A.J. Hilliker, and J.P. Phillips, Motor neurons, reactive oxygen, and life span in Drosophila,Neurobiology Aging, 20,1999, 531-535.

[5] G. I. Arimura, C. Kost, and W. Boland, Herbivore-induced, indirect plant defenses, Biochem BiophysActa, 1734 (2), 2005 , 91 111.

[6] J. Peng, X. Deng, J. Huang, S. Jia, X. Miao, and Y. Huang, Role of salicylic acid in tomato defense against cotton bollworm, Helicoverpa armigera Hubner,Z Naturforsch C, 59 (11-12), 2004, 856-862.

[7] T. Arakawa, Superoxide generation in vitro in lepidopteron larval hemolymph,Journal of insect Physiology, 40, 1994, 165-171

[8] S. Ahmad, Biochemical defence of pro-oxidant plant allelochemicalsby herbivorous insects,BiochemicalSystemics and Ecology, 20,1992, 269-296

[9] G. W. Felton, and S. S. Duffey, Protective action of midgut catalase in Lepidopteron larvae against oxidative plant defenses,Journalof Chemical Ecology, 17,1991, 1715-1732.

[10] S. MD. Akbar, H. C. Sharma,S. K. Jayalakshmi, and K. Sreeramulu, Interaction of plant cell signaling molecules, salicylic acid and jasmonic acid, with the mitochondria of Helicoverpa armigera, Journal of Bioenergetics andBiomembranes, 44,2012, 233241 .

[11] J. Durner, and D. F. Klessig, Salicylic acid is a modulator of tobacco and mammalian catalases,Journal of Biological Chemistry, 271(45),(1996) 28492-501.

[12] Y. Wu, Study on the interaction between salicylic acid and catalase by spectroscopic methods,Journal of Pharmacological and Biomedical Analysis, 44 (3),2007 796-801.

[13] N. D. Charalambidis, C. G. Zervas, M.Lambropoulou, P. G. Katsoris, and V. J. Marmaras, Lipopolysaccharide-stimulated exocytosis of nonself recognition protein from insect hemocytes depend on protein tyrosine phosphorylation, European Journalof Cell Biology, 67,1995, 32-41.

[14] O. H. Lowry, N. J. Rosebrough, A. L. Farr, and R. J. Randall,Protein measurement with the folin phenol reagent,Journal of Biological Chemistry,193,1951, 265-75.

[15] H. Aebi,Catalase in vitro,Methods in Enzymology, 105,1984, 121-126.

[16] B. J. Davis, Disc Electrophoresis-II: Method and Application to Human Serum Proteins, Annuals of New York Academy of Sciences, 15,1964, 404-27.

[17] W., Woodbury, A. K. Spenser, and M. A. Stahman, An improved procedure using ferricyanide for detecting catalase isoenzymes. Annual Biochemistry, 44, 1971, 301-5.

[18] G. W. Felton, and C. B. Summers, Antioxidant systems in insects, Archives of Insect Biochemistry and Physiology, 29, 1995, 187-97.

[19] S. Ahmad, and R. S. Pardini, Mechanisms for regulating oxygen toxicity in phytophagous insects,Free Radical Biology and Medicine, 8,1990, 401-13.

[20] H. V. Remmen, M. D. Williams, H. Yang, C. A. Walter, and A. Richardson, Analysis of the transcriptional activity of the 50flanking region of the rat catalase gene in transiently transfected cells and in transgenic mice,Journal of Cell Physiology, $174,1998,18-26$ 